\title{
Studies on Persian Passion Play (ta'ziya): An Annotated Bibliography
}

\author{
Mahnia Nematollahi Mahani \\ Binesh Institute for Persian Studies, Evanston, USA
}

\begin{abstract}
Persian Passion Play (Ta'ziya), the most important Shiite religious ritual, performed by non-professional actors and musicians, is based on the martyrdom of the third Shiite Imam, Husein, and his companions at Karbala (in 680). This paper aims to introduce a wide range of sources, both books and articles, on the history, music, actors, and arrangements of ta'ziya performance in Iran from 1971 onwards. It includes a number of titles of ta'ziya manuscripts, and the place of performance. The article contains traveler accounts from sixteen century onwards and the translations of ta'ziya texts in European languages.
\end{abstract}

Keywords: Ta'ziya, Martyrdom of Imam Husein, ta'ziya in Persian literature, history, music, manuscripts, travellers' accounts

Persian Passion Play (ta'ziya), the most important and effective form of religious ritual for the Shiite Muslims all over the world, rooted deeply in the beliefs of the Shiite communities. Most Shiites, consciously or unconsciously, are following the symbols, signs and religious and ethical patterns presented during ta'ziya performance. Despite the fundamental importance of ta 'ziya in Iranian cultural patterns, studies on the topic are limited. A research is conducted on the topic to gather the books, articles and travelers accounts and add them to the chapter titled Studies on Persian Passion Play in previously published book on Ta 'ziya. ${ }^{1}$

This article aims to discuss the nature of the books, articles and traveler accounts published on Ta'ziya in order to aid those wishing to contribute, and the scholars and the students in the field of Iranian Studies and Middle Eastern Studies interested in Persian Passion Play.

Scholarly research on passion play commenced with the publishing of Peter J. Chelkowski's 1971 article Dramatic and Literary Aspects of Ta'zieh-khāni Iranian Passion Play. Notably, this piece offers a general and clear overview of ta'ziya performance's various aspects such as its historical development, players, place of performance and its decorations, and its embedded narrative and mystical elements (Chelkowski, 1971). In the same year (1971) another book was published by Parviz Sayyād titled Ta 'ziya Hurr. This ta'ziya was, partly, written and performed by Seyed Mustafā Kāšāni. In 1346/1967 ta'ziya Hurr performed in the city of Shiraz in the assembly of art (jašn-e hunar) (Kāšāni, 1350). Sādiq Humāyūni published a scholarly work on ta 'ziya in 1975 entitled Ta'ziya va ta 'ziya-khāni (Ta'ziya and Reciting Ta'ziya). Aside from addressing the historical roots of passion play, this book examines the text, instruments and characteristics of the players . Also of significance, it contains the following ta'ziyas, in addition to several medieval manuscripts of ta'ziya texts :

\footnotetext{
Mahnia Nematollahi Mahani, Ph.D., Chair \& President, Binesh Institute for Persian Studies.

1 An abridged version of the article under the title of "Studies on Persian Passion play" published in Mahnia A. Nematollahi Mahani, The Holy Drama: Persian Passion Play in Modern Iran (Leiden: Leiden University Press, 2013).
} 
ta'ziya Qāsem, ta'ziya 'Abbās, ta'ziya Imam Rezā and ta'ziya hazrat -e Ma'sūma (Humāyūni, 1354). The first two illustrate the tragic events happened in Karbalā. Humāyūni published another study in 1989 titled Ta'ziya dar Iran (Ta'ziya in Iran). He discusses a wide range of topics including but not limited to the history of ta'ziya and its roots, how ta'ziya developed in Iran and how it declined. The writer says that aristocracy is the main reason for the destruction of ta'ziya. He gives valuable information about different types of ta'ziya, the composers and how both Iranians and foreigners discussed ta'ziya. Humāyūni writes about the instruments used in ta'ziya, the copies and the order of reciting ta'ziya during performance and the famous ta'ziya reciters (ta 'ziya-khānān) and the place of ta'ziya performance. The book contains a large number of ta'ziyas, such as ta'ziya of 'Abbās, ta'ziya of Imam Rezā, ta'ziya of 'Ali Akbar, ta'ziya of Qāniqā shāh-e farang (Qāniqāa, the king of a foreign country). The book is illustrated with a large number of photographs and manuscripts. In 1998, Sādiq Humāyūni published a brief survey on the historical origins and development of ta'ziya in Iran called Shirāz khāstgāh-e ta 'ziya (Shiraz: the Original Home of Ta'ziya) (Humāyūni, 1377).

Citing another source of literature on passion play, several ta'ziya texts are published (2535/1976) by Zahrā Eqbāl titled Jung-e šahādat (The Anthology of Martyrdom). For writing this book, she uses a manuscript with the same title. The book contains 33 ta'ziyas that A.E. Chodzko bought them when he worked in Tehran as the deputy of ambassador of Russia. Later, he dedicated the book to the National Library of Paris. ${ }^{2}$ Jāber 'Anāsuri collected a number of Ta'ziyas in a collection titled Ta ziya: namāyeš-e musibat (Ta'ziya: Displaying Disaster) (2535/1976). The compiler arranges them in chronicle order. It begins from ta 'ziya Qābil, then ta'ziya nār-e Namrūdi [gulestān-e ātaš], and ends to the majles-e zawwār-e bārgāh-e Imam Rezā (the assembly of the pilgrims of Imam Rezā shrine), the eight Shiite Imām. ${ }^{3}$

Another scholar Mahmoud Ayoub explores how ta'ziya performance and the conceptualization of Husein's death have been derived from the traditions later attributable to the Prophet Mohammad in his work Redemptive Suffering in Islam (1978). Such Prophetic traditions are used to show that the angels informed the Prophet about Huseyn's cruel death to promote a sense of legitimate leadership amongst the audience. Ayoub further elaborates the latent effects of ta'ziya on the Shiite Iranians. For instance, Shiites actively participate in ta'ziya to receive heavenly rewards. Their act guarantees their eternal life in Paradise. Ayoub also examines the growth and expansion of ta'ziya performance in various periods. He describes the places, instruments and their symbolic meanings, and the audience's reactions. The importance of lamentation poetry (marāthi) and its development in regards to the motives related to Husein's death is another subject that is treated in his book. Ayoub shows how the Shiite Muslims treat Husein's tomb as a sacred sanctuary (haram) (Ayoub, 1978).

In 1979, an invaluable collection of articles on the topic under the title of Ta 'ziyeh: Ritual and Drama in Iran, edited by Chelkowski, was published. As the outcome of a symposium organized by the Shiraz Festive of Arts in the summer of 1976, the book deals with yet another aspect of ta'ziya: its origin, method of performance and symbolic meaning of the instruments, cultural dimensions, and its roots among Iranians before Islam. The literary and musical progressions of ta'ziya, as well as its philosophy are studied. Several articles are dedicated to addressing the extent to which Western-style theater is influenced by ta'ziya.

Moreover, Chelkowski published an article in 1984 titled "Islam in Modern Drama and Theater", in which he illustrates various theatrical plays in Iran such as naqqāli, rūhowzi, kheymašab-bāzi and rowza-khāni. Chelkowski enriches this study with analysis of the development of written drama in Iran and Middle East in

\footnotetext{
2 Jung-e šahādat. be ehtemām-e, Zahrā Nāmdār. Tehran: Soroush, 2535/1976.

3 Ta ziya: namāyeš-e musibat. 1365. be kūšeš-e J. 'Anāsuri, Tehran: entešārāt-e Jahād-e Dānešgāhi.
} 
conjunction with the social changes surrounding theater. He goes on to explain various aspects of several rare ta'ziyas, namely, Zekr-e Mụsibat-e bar dār kardan-e Mansūr Hallāj rahmatullāh 'aleyh (a remembrance of the tragedy of Hallāj on gallows 'God blesses him') (Chelkowski, 1984).

Michael M.J. Fischer's Iran: from Religious Dispute to Revolution (1980) sheds light on the political conflict over passion play performance between several Iranian intellectuals and modern Shiite "ulama such as Khomeini and Kasravi (Fischer, 1980, pp. 133-4). The author mentions that, in the city of Yazd, several objects, such as a mirrored nakhl, are carried as symbols of Husein's martyrdom and the captivity of his family. In three small villages outside of the city, parades represent Husein's martyrdom. He further draws a comparison between the biblical story of Joseph and his brothers, with the Qur'ānic story and ta'ziya texts with the intention of showing that for the Shiites, the concepts of sacrifice and suffering have a deep meaning. Fischer additionally discusses 'Āšūrā from historical and ethnographical perspectives to demonstrate how these events and their consequences have evolved into a remedy for social problems (Fischer, 1980, pp. 170-7).

In 1981, Hamid Naficy published a praiseworthy article titled "Cinema as a Political Instrument" in Modern Iran: The Dialectics of Continuity and Change. This article consists of two parts: The first part is on ta'ziya, and the second is written about rūhowzi, which is not the subject of this article. After a brief reference to the foreground of ta'ziya, Naficy asserts the reasons for which on the one hand the "ulamās and on the other hand the Pahlavi monarch, Rezā Šāh (r.1925-1941), were not interested in ta'ziya performance. In addition, he shows why intelligentsia appreciated ta'ziya as an art form. Naficy explains why and how rowza-khāni connects the events of 'Āšūrā with Iranians' daily lives and that how ta'ziya "symbolic characterizations have deep meaning in Iranian cultural context" (Naficy, 1981, pp. 341-81).

A scholarly article written by Mary Hegland (1983) titled "Two Images of Huseyn: Accommodation and Revolution in an Iranian Village" is also worth mentioning. Poignantly, she stresses the influence of Husein's martyrdom on the formation and victory of the Islamic Revolution. She assesses that the Shiites of Iran believe in Husein's intercession on the Day of Judgment. According to Hegland, Husein's death at Karbala becomes a focal point during the Islamic Revolution, and further, that he became the archetype of protest against the tyrannical Umayyad caliph, Yazid (r. 680-83), which Iranians sought to emulate. Furthermore, the author describes how the passive concept of hope for intercession shifted to the active protest against the Pahlavi regime. In other words, every one aspired to the ideal, inspired by Husein, of bravely standing up to a totalitarian regime (Hegland, 1983, pp. 218-35).

Adabiyyāt-e namāyeši dar Iran (The Performance Literature in Iran) in two volumes by Jamshid Malekpour (1984) is an invaluable work. He has dedicated the fifth chapter of the first volume to the ta 'ziya. In this part Malekpour focuses on one of the sources that effectively developed ta'ziya performance in tenth century: Rowzat al-Šshadā (The Garden of the Martyrs) by Mullā Husein Wā'ez Kāšefi Sabzevāri. Malekpour re-states the episode written about Fatima's behavior after the death of his father, the prophet Muhammad. She does not survive long after his father's death. Malekpour shows how Wā'ez Kāšefi changes this event to a story. Afterwards, he adds several ta'ziyas referring to the death of Fatima and her passionate talk with her husband, 'Ali Ibn-e abi-Tāleb, her children, Hasan, Husein and Zeynab. Moreover, in his work Malekpour illustrates the major role of geographical and social construction of Iran on formation of the ta'ziya symbols. For instance, he holds that due to the lack of water in Iran ta'ziya composers repeatedly refer to the act of Ibn-e Ziyad's army. They blockade water to Imam Husein and his companions in the plain of Karbala. Effectively, Malekpour makes a subjective division to ta'ziya: the incident (vāqe'a); before the incident (piš-vāqe'a); and gūša. Then he 
adds, the form similar to comic (šabih-e muzhek) to show how ta'ziya performance has developed during the history and the comic elements are added to it. His book is illustrated with several manuscripts of ta'ziya texts and illustrations (Malekpour, 1363, pp. 211-63).

In 1985, the journal The Drama Review published yet another article on ta'ziya by Chelkowski titled "Shia Muslim Processional Performances". In it, he sketches the development of ta 'ziya performance from its Buyid dynastic beginnings (352/963) to the victory of the Islamic Revolution (1357/1970). Chelkowski also discusses various paraphernalia, such as nakhl or horses, prepared for performances, as well as places where ta'ziya has been performed like open and enclosed areas, streets, and tekiyya (Chelkowski, 1985, pp. 18-30). In 1986 Chelkowski published two articles in al-Thirāt magazine with the title "Popular Shî‘'i Mourning Ritual" in which he discusses ritual performance in the Middle East in Arab, Persian, Turkish and Urdu communities (Chelkowski, 1986). In another article in the same source, "From Maqātil Literature to Drama", Chelkowski illustrates how Husein's death is depicted in ta'ziya texts written by Arab composers. At the end of this article the author offers a translation from a ta'ziya entitled, The Martyrdom of the Luminous Leader of the Bani Hāshim, Hazrat abū 'l-Fazl al-'Abbās (Chelkowski, 1986).

Another scholarly work by Jamshid Malekpour is seyr-e tahavvol-e mazāmin dar šabih-khāni (ta'ziya) (The Evolution of Motifs in šabih-khāni) published in 1987. The book has five chapters, in the second chapter, Malekpour writes how Iranians familiarity with plays such as qessa-khāni, maddāhi, lu'bat-bāzi and religious epics (hemāsehā-ye dini) such as khāvar-nāma and hamla-ye Heydari played an important role in constructing ta'ziya performance, and the poetry of the Safavid period. The author shows the similarities between an excerpt from Rowzat al-Šshadā by Mullā Husein Va'ez Kāšefi and a majle-se ta'ziya compiled about three centuries after Kāšefi by Alexander Khochkow. In the third chapter, Malekpour shows that the Persian Drama is not derived from its European counterpart. It has its own roots in the history and literature of Iran. In addition, he explains that šabih-khāni has an effective role in preserving and development of music in Iran, the musical instruments used in this form of play and the role of player and the scene. In this chapter, the writer explains about tekiyya dowlat and its form and construction. In the forth chapter, he writes about the development of šabih-khāni and the parts that are added in the course of time. Those are the assemblies that are not a complete story and are called piš-vāqe'a (before incident). They function as an introduction for the main story. The book is illustrated by several scenes of Imam Husein fight against Yazid and ta'ziya performances, it is consists of ta'ziya manuscripts and the following four majles-e ta'ziye: (1) qurbāni kardan-e Esmā'il dar rāh-e khudā (Sacrificing Ismael in the Path of God); (2) šahādat-e Imam Husein (the Martyrdom of Imam Husein); (3) Amir Teymūr va vāli-ye Šām (Amir Teymūr and the Governor of the City of Damascus); (4) māliyāt gereftan-e jenāb-e Mu'in al-Bukā' (Mr. Mu'in al-Bukā' Is Asking for Tax) (Malekpour, 1366).

Another commendable body of research has been produced by David Pinault. In his study The Shiites: Ritual and Popular Piety in a Muslim Community (1992). He hones in on a particular aspect of Shiism within the context of the ta 'ziya ritual in India (Pinault, 1992). One of Pinault's articles entitled "Zaynab bint 'Ali and the Place of the Women of the Households of the First Imāms in Shiite Devotional Literature" published in 1998 is another attempt to get a handle on the topic, in which he asserts Zeynab's protest in the court of Yazid after the battle of Karbala provided a model of activism for Iranian women during the Revolution. He further goes on to explain how Fatima, the Prophet's daughter and Husein's mother, has become a role model for Iranian women (Pinault, 1998). 
In 1993, Johan G.J. ter Haar published an invaluable article on Passion play performance in Iran under the heading "Ta'ziyeh: Ritual Theater from Shi'ite Iran" (Ter Haar, 1993). An invaluable collection on the subject titled Šabih-khāni, ganjina-ye namāyešhā-ye 'ā'ini, mazhabi (1993) collected by Jāber 'Anāsuri is the output of a conference held in 1371/1992. The article titled "Šabih-khāni durr-e yatim-e namāyešhā-ye Irāni” (Reciting Alike: The Unique Pearl of Iranian Theater) covers a wide range of subjects about ta'ziya performance. For instance, the symbols used in ta'ziya performance, the language of texts, the symbolic meaning of clothing and colors and the characteristics of protagonists and antagonists. 'Anāsuri illustrates how ta'ziya performance connects the audience with historical events such as the cruel death of Siyāvuš, the son of Keykāvūs the mythical king of Iran, by the order of the king of Tūrān; Afrāsiyāb. The writer shows how in ta'ziya the composer mingles the historical events to elevate the position of the Prophet, Muhammad, family. For this purpose, he refers to the assembly of 'Rustam va Suleymān'. In this ta'ziya Rustam, the Iran's mythical hero, meets the first Shiite Imam 'Ali. The former converts to Islam ('Anāsuri, 1372b). Elhām Rahim-'Ali wrote on origin of ta'ziya. Her article titled "Manša'e ta'ziya" (The Origin of ta'ziya) is translated by Mustafā Tālebi. Rahim-'Ali provides the reader with some information about the restrictions imposed on Shiites and consequently on ta'ziya performance at Āzarbāyjān and Caucasus from ninth century by the order of the caliph al-Mutawakkel (847-851) until the advent of the Safavid dynasty (1501-1722) that entailed to Shiites power and progress of ta 'ziya performance (Rahim-'Ali, 1372, pp. 45-52). Husein Muhammadzāda-Seddiq introduces the book Hadiqat al-Su 'adā' (The Garden of the Fortunate People) by Mullā Muhammad Fuzūli in 10th century. The book consists of four parts (rukn): The first is on "the essence and understanding knowledge, knowing God and types of science"; the second part is "the beginning of the creation of the world and skies"; the third part is "on God's essence and His epithets, the most highest"; the last part discuses "the man's need to the prophets and the prophet hood of the most generous Prophet (PBUH)" (Muhammadzāda-Seddiq, 1372, pp. 53-74). The next article in the collection that treats the subject is "Majles-e šahādat-e "Ali Akbar (PBUH)" by Robert Henry du Zhanr. After a short introduction about the assembly of ta'ziya and the reaction of the audience during ta'ziya performance, in brief, the writer illustrates the scene and the players. Afterwards, he offers several parts of Majles-e šahādat-e 'Ali Akbar. ${ }^{4}$ Another scholarly work in this collection titled "Ta'ziya dar miyān-e musalmānān-e Shi'a" (Ta'ziya among the Shiite Muslims) by Peter Chelkowski shows that the Shiites of Iran, Iraq, and Caucasus use similar symbols to commemorate the martyrdom of Imam Husein and his companions (Chelkowsiki, 1372, pp. 106-118). Another comprehensive article on the subject is "Pišina va tārikhča-ye ta "ziya dar Iran” (Background and the Short History of Ta'ziya in Iran) by Javād Amini. He makes several references to the travel accounts to show that ta'ziya was performed from Buid period onwards. The writer shows the subjective change in ta'ziya from a tragedy to comic in Qājār (1779-1925) period. Ta'ziya Amir Teymūr is an example of comic ta'ziyas that the writer explains its episodes. Furthermore, he illustrates the characteristics of the antagonists and protagonists in the mentioned ta'ziya (Amini, 1372, pp. 119-35). Two articles are written about ta 'ziya performance in Afghanistan and Pakistan, Iran's neighborhood countries. “Ta'ziya va marāsem-e 'azādāri dar afḡānestān” (Ta'ziya and Mourning Rituals in Afghanistan) by Hamid Ahmadi (1372, pp. 137-154). Jāber 'Anāsuri elaborates on reception of ta'ziya and mourning for Imam Husein in Pakistan in an article titled "Ta'ziya va marāsem-e 'azādāri dar Pākestān" (Ta'ziya and Mourning Rituals in Pakistan) ('Anāsuri, 1372, pp. 155-63). In this collection Jāber "Anāsuri offers another article titled "Bahr-e

\footnotetext{
${ }^{4}$ Du Zhanr, Robert Henry. 1993. "Majles-e šahādat-e 'Ali Akbar (PBUH)”. In Šabih-khāni, ganjina-ye namāyešhā-ye 'ā’ini, mazhabi, be kūšeš-e J. 'Anāsuri. Tehran: Čāpkhāna-ye Rāmin, pp. 75-92.
} 
tavil khāni: šiva'i az petwāzh gūi va manzūma-khāni-ye namāyeši dar qalamrow-e šabih-khāni 'durdānahā-ye sukhan bar sulk-e mehan" (Reciting Long-meter: A Method of petwāzh and Reciting Performance Narrative in the Realm of šabih-khāni, Eloquent Pearls on the String of Grief). 'Anāsuri explains the important role of long meter (bahr-e tavil) in motivating audience. It is more effective when it is recited while the player moves on the stage. He shows that in ta'ziya performance both protagonists and antagonists recite this meter to boast his lineage and power ('Anāsuri, 1372, pp. 165-186). Muhammad-Rezā Behnūdi provides the reader with documents about ta'ziya in Tekyya Dowlat "Asnād-e vizha-ye šabih-khāni dar Tekiyya Dowlat" (Valuable Documents on šabih-khāni in Tekiyya Dowlat) (Behnūdi, 1372, pp. 187-95). Mustafā Mukhtābād in his article "jāygāh-e zibā-šenākhti-ye tatbiqi: ta ziya dar te'ātr-e mu'ạ̄ser-e jahān" (The Position of Comparative Aesthetics: Ta'ziya in the World's Modern Art) draws a comparison between ta'ziy and the theater by Bertolt Brecht, a German poet, playwright, and theater director. Mukhtābād shows how Brecht tries to traverse the time and space between player and audience; while they are separate. He holds that in ta'ziya performance the player distinct himself from the real characters by using several methods. For instance, a player may read from the text or talk with the audience during performance (Mukhtābād, 1372, pp. 197-215.). Behina Khušnevisān in her work "Naqš-e lebās dar ta'ziya" (The Role of Dress in Ta'ziya) explains the types of ta'ziya dresses and the role of the color in illustrating the role of the player (Khušnevisān, 1372, pp. 217-233). Metin And's work titled "Ta'ziya: Tragedy dar Islam" (Ta'ziya: Drama in Islam) offers similarities between ta'ziya and the Greek tragedy. For instance, in ta 'ziya texts Imam Husein offers his head to save his nation; the same role is given to the Greek heroes. They suffer affliction to rescue the people from punishment in the hereafter (And, 1372, pp. 235-247). In 1994 Milla C. Riggio wrote an invaluable article on ta'ziya. He refers to ta'ziya performance as an Iranian art that distinguishes them from Arab Muslims. This religious performance enables Iranians to maintain a sense of national identity, according to the author. He provides the reader with a brief history of ta'ziya and its function in modern Iran. He refers to the participation of the audience in the performance and their assistance in serving foods and beverages as a feast where they renew their commitment to religious values. Riggio refers to ta'ziya procession and ritual as a political tool for changing the local or central power. During ritual, union of the audience with the state's principles ends to oneness of their identity with the historical event (i.e. Husein martyrdom). At the end of ta'ziya play the community celebrates both martyrs and martyrdom. The colors that the players use for their clothing show the victory of the martyrs and their innocence as the writer says. In his article, the author explains the ta'ziya of Moses and the Wandering Dervish directed by the Persian director Mohammad Ghaffari living in America. Riggio explains how the main narrative is adopted for an American audience, and in spite of difficulties, how Ghaffari used symbolic instruments (i.e., fire) to convey the message to his non-Iranian audience who like Iranians were sitting on the floor to see the ta'ziya performance. The writer illustrates the differences between the ta'ziya and its original counterpart and the audience reactions. The article is illustrated with several images from the ta'ziya of Moses and the Wandering Dervish (Riggio, 1994, pp. 115-140).

Lāla Taqiyān provides the reader with general information about Iranian ta'ziya and theater in her book Dar bāra-ye ta 'ziya va te'ātr dar Iran (About Ta'ziya and Theater in Iran) published in 1995 (Taqiyān, 1374).

The Administrative and Social History of the Qajar Period [The Story of My Life] (1997) by Abdullah Mostowfi, translated by Nayer Mostofi Glenn, is an autobiographical chronicle of ta'ziya performance during the Qājār period. Mostowfi conveys how Nāser al-Din Shāh changed the commemoration of Husein's martyrdom into a rationale based on pleasure and ostentatious luxury throughout the course of his reign. The 
author mentions that ta'ziya composers put in a great deal of effort more so to mobilize their audience, rather than develop the plot. He describes the appearance of protagonists and antagonists, the role of Mu' in al-Bukā' in the stage, and the parade of more than 200 camels before Nāser al-Din Shāh. Mostowfi also provides an account of a ta'ziya that was performed in the house of Ezzat ol-Dowleh, the sister of Nāser al-Din Shāh (Mostowfi, 1997, pp. 163-170). Of significance, it demonstrates that the religious aspects of ta'ziya performance were not of great importance to the Shāh.

In 1999, Mohammad Faique published a scholarly work titled A Complete Study of Persian Drama 1906-1995. In the second chapter of his book, Development of Drama in Persian Language, Faique addresses the history of performance in Iran. He asserts that different forms of play such as 'šabih' came into being toward the end of 18th century, during the reign of Fath-'Ali Shāh Qājār. The author explains the background of ta'ziya and its ritualistic importance for Iranians. Although the plays were performed at the court to amuse the king, the majority of the audience, attended the performance, were ordinary people. Faique explains the development of ta'ziya and refers to šamāyel-gardāni (moving portraits around) as a religious form of play, and naqqāli (storytelling) as a non-religious performance. The writer says that Iranians' foreground knowledge and experience in storytelling is a reason for making them strong players of ta'ziya (Faique, 1999, pp. 65-86).

In the second chapter of his book Hosay Trinidad: Muharram Performances in an Indo-Caribbean Diaspora (2003), Frank J. Korom writes about Muharram rituals in Iran. The author shows the historical roots of ta'ziya in Iran rely on Shāhnāma (The Book of Kings) by Hakim Abu al-Qāsem Ferdowsi (ca.935-1020). He explains similarities between the assassination of Siyavush, a hero of Shāhnāma, and Husein, the third Shiite Imam. Veneration of Husein martyrdom that was limited to the influential members of his clan spread throughout the Shiites community from tenth century when the Shiite Buyid dynasty (945-1055) came to power, according to Korom. He gives a short, but useful, historical information about ta'ziya performance and moves to the literary genres that emerged along with the expansion of the mourning rite. He explains the topics including maqtal-khāni, rowza-khāni, guriz, and marthiya-khāni. Aside from addressing the historical functions of ta'ziya, Korom examines how ta'ziya is performed in modern Iran and how it affects the feelings of the spectators and their beliefs. Also of significance, the book contains valuable information on objects used during Muharram mourning, religious fatwas on flagellation, the meaning of the nakhl and its symbolic function during Muharram rituals. The book is illustrated (Korom, 2003, pp. 32-52).

Another praiseworthy work by Jamshid Malekpour is The Islamic Drama (2004). The writer asserts that for understanding ta'ziya and its nature one needs to understand Islam and its history. For this reason, he starts his work with the pre-Islamic history of Iran and asserts that Yädgār-e Zarirān may be seen as the first work that played major part in religious drama in Iran. He gives valuable information about the traveler accounts and their observations. Malekpour provides the reader with valuable information about a form of mourning ritual in ancient Egypt. He draws a comparison between the death of Osisris, the Greek hero; Siyāvush, the Iranian prince and Imam Husein, the martyr of Karbala, to show the theatrical elements that connect these performances together. In the next chapter, the writer illustrates how ta'ziya was used in Safavid period (1501-1722) as a national icon to unify the Iranian population and mobilize them to resist against Ottomans and the Uzbeks, the neighbor countries who attacked Iran several times. For this purpose, the Safavid kings motivated the poets to write elegies about Husein and his martyrdom also a group of readers or tellers called rowza-khān explained the tragic events of Karbala. Storytelling, parda-dāri, and music and their influence in 
development of ta'ziya are other subjects treated by the writer. Malekpour gives an accurate analyze of a prologue, an episode, a sub-episode and a comic episode to offer a better understanding to the reader. The work contains several manuscripts and illustrations (Malekpour, 2004).

Kamran Scot Aghaie published a scholarly work in 2004 entitled Martyrs of Karbala: Shi 'i Symbols and Rituals in Modern Iran, in which he illustrates how the event in Karbala has transformed from a historical event to a symbolic paradigm and has been used in various time periods in the form of ta'ziya ritual to legitimize the state. The Pahlavi dynasty (1925-1979) is an exception in this regard, as it tried to suppress ta'ziya performance in order to restrict its political influence. Aghaie importantly discusses how ta'ziya served the political purpose of the Qājārs, who ruled between 1796 and 1925, and the 1979 Islamic Republic of Iran. The Qājar elites in particular partook in ta'ziya performance, which essentially represented their integration with the indigenous people. In other words, ta'ziya served as a social bond, which connected them to society. Conversely, the Islamic Republic creates a religious identity from the ta'ziya rituals to motivate the common people to overthrow the secular Pahlavi regime and later used them to mobilize youth to take part in the fight against Iraq between 1980 and 1988 (Aghaie, 2004).

In 2004, 'Ali Bulūkbāši published a comprehensive work titled Ta 'ziya-khāni hadith-e masā'eb-e qudsi dar namāyeš-e à'ini (Performing Ta'ziya: Holy Tradition of Tragedy in Ritual Play). This study illustrates historical aspects of ta'ziya and its effective influence on Iranians as a holy religious ritual (Bulūkbāši, 1383).

A collection of articles about passion plays was published in The Drama Review Journal (2005). As an introduction, Rebecca Ansary Petty (2005) offers a translation of a ta'ziya titled "The Ta'ziyeh of the Martyrdom of Hussein”. The rest of the articles in this volume cover a wide range of topics: Sādiq Humāyūni's (2005, pp. 68-72) article "A View from the Inside the Anatomy of the Persian Ta'ziyeh Plays" deals with the poetry, music, place and performance of ta 'ziya. "Acting Styles and Actor Training in Ta'ziyeh" by William O. Beeman and Mohammad B. Ghaffari examines the artistic skills required from ta'ziya players. For instance, a player is expected to know how to fight, run, and do other athletic movements while singing. Additionally, they consider the influence of ta'ziya on modern media such as Hollywood films (Beeman \& Ghaffari, 2005, pp. 48-60). Peter Chelkowski, in his article "From the Sun-Scorched Desert of Iran to the Beaches of Trinidad Ta'ziyeh's Journey from Asia to the Caribbean", studies how ta'ziya performance migrated from Iran to India. More specifically, he concentrates on explaining nakhl: meaning its production process and the symbolic meanings of objects associated with it. Chelkowski shows various developments of ta'ziya from India to the Caribbean, where ta'ziya has become both a symbol of pan-Indian unity and the community of Indians (Chelkowski, 2005, pp. 156-170). In 2005, yet another informative work published on ta'ziya by Heizn Halm in Germany. His book is translated into English by Allison Brown, titled The Shi'ites: A Short History. In the second chapter of his book, Halm examines the historical origins of 'Āšūrā and Imam Husein martyrdom. The author relies on the reports from the Europeans who traveled to Iran during the Safavid dynasty (1501-1736), and the elegies written for Imam Husein and his family during the period. Relying on travelers' accounts, Halm describes ta'ziya scenes, mourning processions and self-flagellations. He asserts that Shiite self-flagellations are similar to the Christians flagellations. His book is illustrated with paintings and images from procession mourning. ${ }^{5}$ In the same year (2005), Hamid Dabashi published a valuable article in The Drama Review Journal under the heading "Ta'ziyah as Theater of Protest". He explains how ta'ziya impacted on Iranian consciousness

\footnotetext{
5 The Shi ites: A Short History, 2005. Translated by A. Brown. Princeton: Markus Wiener Publishers.
} 
to actively participate in the revolution and overthrow the Shah. Dabashi shows the inner relationship between players and audience and the latter's awareness of the performance, the play and the theme. Ta'ziya, deeply rooted in the Shiites of Iran, configured the Revolution of 1979, and the war between Iran and Iraq (1980-88) according to the author (Dabashi, 2005, pp. 91-99).

Another informative contemporary text on ta'ziya is Negar Mottahedeh's "Karbala Drag Kings and Queens". Here, she observes the role of gender in ta 'zia performance, which, in turn, leads to an important discourse on national identity. Mottahedeh claims ta'ziya performance differs amongst Iranian Twelver Shiite in Iran and its neighboring countries, and that through studying ta'ziya, one may understand the concept of Otherness in respect to Iranians (Mottaheded, 2005a).

Another scholarly work on the subject is The History of Theater in Iran by Willem Floor (2005). The book contains valuable information about various types of entertainments in Iran. For instance, comic drama, puppet drama, and narrative drama then he elaborates on ta'ziya in the fourth and fifth chapter of his work. In the chapter four titled Elegy Recitation or Marthiya-khāni (reciting elegy), Floor refers to the history of the ta'ziya performance, its beginning and development from Buyid dynasty (963) onwards. He shows how lamentation for Imam Husein takes different forms. For this purpose he explains how rowza-khāni came to existence in Safavid period under the influence of Rowzat al-Šuhada' by Husein Wā'ez-e Kāšefi. In this time, other sources were popular for lamenting Imam Husein death according to Floor. For instance, marthiyas and Karbala stories, the "Strom of Weeping" (Tūfan al-Bukā) of Muhammad Ebrahim b. Muhammad Baqer Haravi Qazvini Jowhari (d.1253/1837-8). Floor provides the reader with valuable information about the place where rowza-khāni performed, its supporters and the rowza-khāns. In this chapter Floor gives valuable information about parda-dāri or picture narration. According to Floor, other groups such as wandering dervishes (1694) and individual dervishes used picture to tell story about their masters for the audience. In the fifth chapter titled Religious Epic Drama, Floor holds that rowza-khāni and parda-dāri are the primary forms that lead to ta'ziya performance. From which two form of entertainment emerged. The first one mimed the grief believers felt for the martyrdom of Imam Husein. The second one was the association that prepared scene and various tools to commemorate Imam Husein martyrdom at Karbala. The writer refers to several traveler accounts to show how theatrical tools were used for ta'ziya performance. Floor quotes from Della Valle and Chardin that in this period several men colored themselves from head to toe in black or red, they were naked except for their private parts. The black color showed misery he felt over Imam Husein death and red represented his cruel death. The writer shows that how various elements existed in previous periods developed later. He asserts that ta'ziya does not originate from European theater. In this chapter, Floor offers valuable information about tekiyya, the place where ta'ziya performed. He explains both temporary and permanent tekiyyas, and offers a vivid explanation about Tekiyya Dowlat, the building was constructed by the order of the Qājār king, Nāser al-Din Shāh (1831-1896). Afterwards, Floor illustrates how financing a ta'ziya performance is considered as a pious act. The supporter is doing this act to receive heavenly reward (thavāb) in the hereafter. For this reason, not only the Šāh and the rich people financed a stage but also the ordinary people paid for building a tekiyya in every part of the town. The author asserts that the rich individuals dedicated endowment funds (vaqf) to ensure that Passion play takes place after their death. In addition, he tackles the characteristics of the ta'ziya texts, the stage, the actors and customs. Afterwards, Floor illustrates the process that a mourning assembly is performed. It begins with rowza-khāni that is reciting the tragic events of Karbala and preparing the audience to weep. It follows by the tragedy, at this stage after passing a funeral procession, the players enter to the scene. Here, 
Floor examines the characteristics of the protagonists, antagonists and director and that by which means the director endeavors to show the scene is real. Amazingly, Floor acknowledges the reader from passion play performed by women in the house of Qamar al-Saltana, the daughter of Fath-'Ali Šāh Qājār. The book is illustrated with photos (Floor, 2005, pp. 107-212).

Yet, another praiseworthy work published in 2005 on passion play is Namāyeš va musiqi dar Iran (Play and Music in Iran) in three volumes by Jahāngir Nasri-Ašrafi. In the third volume he gives several examples from guša in ta'ziya music. Of significance, the book includes the following ta'ziyas: majles-e šahādat-e Imam Husein (the assembly of Imam Husein martyrdom), ta'ziya hazrat-e Muslem (ta'ziya of his Holiness Moslem), namāyeš-e majles-e Mansur Hallāj (the play of assembly of Mansur Hallāj), majles-e ta'ziya dokhtar-e hendu (the assembly of ta'ziya of Indian girl). Before each majles, Nasri-Ašrafi gives a brief overview of the event. This book is illustrated with photos (Nasri-Ašrafi, 1383).

Another collection of articles (2005) is The Women of Karbalä: Ritual Performance and Symbolic Discourses in Modern Shi 'i Islam edited by Kamran Scot Aghaie. The book is illustrated and divided into two parts. In the first part, the articles focus on Iran. The second part deals with the Arab world, South Asia, and the United States of America. In her article "Ta'ziyeh: A Twist of History in Everyday Life”, Negar Mottahedeh argues how the gender dynamics of ta'ziya developed during the Qäjār period. She holds that women were engaged in organizing the ritual (Mottahedeh, 2005, pp. 25-43). "The Gender Dynamics of Moharram Symbols and Rituals in the Latter Years of Qajar Rule" by Kamran Scot Aghaie examines social, psychological and spiritual functions of Shiite symbols and rituals in Iranian women's life in the Qājār period. He discusses how women played in ta'ziya rituals in both public and private rituals (Aghaie, 2005, pp. 45-63). Ingvild Flaskerud's "Oh, My Heart Is Sad it Is Moharram, the Month of Zaynab: The Role of Aesthetics and Women's Mourning Ceremonies in Shiraz", examines the signs and symbols, places and the iconography of the images in modern Shiraz and the fact that women actively participate in ta'ziya rituals to achieve salvation in the physical world and the other world (Flaskerud, 2005, pp. 65-91). In her article "The Daughters of Karbalā: Images of Women in Popular Shi'i Culture in Iran", Faegheh Shirazi (2005) explains the representation of female characters in religious eulogies and chants in modern Iran. She argues that the representations are used to support the Islamic Republic of Iran. "Iconography of the Women of Karbalā: Tiles, Murals, Stamps, and Posters", by Peter J. Chelkowski (2005, pp. 119-160) examines the images of female characters in Shiite religious drama. The writer illustrates how these female characters serve as a model for chastity, purity, and self-sacrifice through which the leaders of the Islamic Republic represented their ideals.

In the second part of The Women of Karbala one reads the following articles: "Sakineh, The Narrator of Karbalā: An Ethnographic Description of a Women's Majles Rituals in Pakistan”, by Shemeem Burney Abbas. She analyses how the narrative voice of Sakina presents gendered themes in mourning rituals in Pakistan (Burney Abbas, 2005, pp. 141-160). In his article "Sayyedeh Zaynab: The Conqueror of Damascus and Beyond”, Syed Akbar Heyder (2005, pp. 161-181) studies how Zeynab is presented in modern Urdu poems and pious elegies. "Gender and Moharram Rituals in an Isma'ili Sect of South Asian Muslims" by Reyhana Ghadially examines how women in the Isma'ili community of Bohra in India tend to be more active in private rituals than public ones. She finds that the women play a major part in universalistic Shiite Ideals (Ghadially, 2005, 183-198). Mary Elaine Hegland's (2005, pp. 199-227) "Women of Karbalā Moving to America: Shi'i Rituals in Iran, Pakistan, and California" draws a comparison between two Shiite communities that have 
migrated to the United States. She illustrates the distinction between them and holds that South Asian women are more active in religious rituals than Iranian women. "Women's Religious Rituals in Iraq" by Elizabeth Warnock Fernea and Basima Q. Bezirgan (2005, pp. 229-230) illustrates that both men and women are active in public religious rituals. They show the supportive role of women in men's rituals and men's supportive role in women's private rituals. The last article of this book is "From Mourning to Activism: Sayyedeh Zaynab, Lebanese Shi'i Woman, and the Transformation of Ashura" by Lara Z. Deeb. She focuses on Shiite Lebanese rituals and their recent changes under the influence of urbanization, modernization and political Shiite parties: Amal and Hezbollāh (Deeb, 2005, pp. 231-266).

Ta'ziya khāni dar šahrestān-e Sirjān (Ta'ziya Performance in the City of Sirjān) by 'Ali-Akbar Vuthūqi-Rahbari (2007). The author provides the reader with valuable information about the historical background of ta'ziya performance in Iran. A characteristic that distinct the work is that it contains manuscripts that illustrate the Sirjān's rich people dedicated their property (vaqf) to survive ta'ziya performance in this city. Vuthūqi-Rahbar explains how ta'ziya performed in the town of Pāriz, Karān and several other villages. He decorates his books with pictures from procession mourning and ta'ziya performance (Vuthūqi Rahbari, 1386).

In 2007, yet another invaluable work on passion play published by Ya'qūb Āzhand titled Namāyeš dar dowra-ye Safavi (The Play in Safavid Period). The author gives useful historical information about ta'ziya performance beginning from sūg-e Zarir (mourning for Zarir), sūg-e Siyāvuš and sūg-e Šervin in ancient Iran. In addition, Āzhand examines two myths from Mesopotamia, titled the myth of Tamūz and the myth of Gilgamesh. Then, he explains how ta'ziya performed in Safavid period. He provides the reader with valuable information about the mourning rituals during the ta'ziya performance, for instance, self-flagellation, self-beating, cutting the body by dagger or sword. In addition, Āzhand refers to the fight between two groups of Sufis called Heydari and Ne'mati, the ritual of sacrificing a camel (marāsem-e shutur qurbāni) in the feast of qurbān ('eyed-e qurbān). The book is decorated with photos (Āzhand, 1385, pp. 17-96).

Emkānāt-e fanni dar te'ātr-e Irān: sahna, nūr, sedā, dekur, lebās va āksesovar (Technical Possibilities in Iran's Theater: Stage, Light, Sound, Decoration, Clothing and Accessvar) by Bābak Shāh-'Alizādegān (2008). The author examines several ta'ziya performances selected from the Europeans' travelers accounts such as Karsten Nybur and Franklin. Shāh-'Alizādegān describes different types of tekiyya, such as contemporary and permanent tekiyyas, their form and usage during the year and their usage during the month of Muharram for ta'ziya performance. He explains how the objects convey different meanings during the play. To draw a sketch of how Tekiyya Dowlat was used, the author relies on both European accounts and the works written by Iranian authors. For instance, Ja'far Mahjub. Shāh- 'Alizādegān (1386) writes about the structure of Tekiyya Dowlat, its decoration and its use for different types of performances. The book contains photos from various takkiyas, caravansaries, the players, and the Tekiyya Dowlat.

A collection of articles on the subject, edited by Peter J. Chelkowski, titled Eternal Performance Ta 'ziyeh and Other Shiite Rituals (2010) covers a wide range of topics on ta 'ziya. As an introduction, Chelkowski (2010, pp. 1-18) writes an article titled "Time Out of Memory: Ta'ziyeh the Total Drama". He offers a general foreground about the origin of ta 'ziyeh, the character and its performance Rebbeca Ansary Pettys' (2010) article is "The Ta'ziyeh of the Martyrdom of Hussein". Her article is published in The Drama Review Journal.

\footnotetext{
${ }^{6}$ Ansary Pettys, Rebeca. 2010. "The Ta'ziyeh of the Martyrdom of Hussein". In Eternal Performance Ta 'ziyeh and Other Shiite Rituals. Edited by P. J. Chelkowski. London, New York, Calcutta: Seagull Books, pp. 19-41. For more information on the article, please see p. 19 of the present article.
} 
Kamran Scot Aghaie (2010, pp. 42-52) writes on "The Origins of the Sunnit-Shiite Divide and the Emergence of the Ta'ziyeh Tradition". "Muharram Ceremonies Observed in Tehran by Iliya Nicolaevich Berezin" by Jean and Jacqueline Calmard examines the travel accounts written by Iliya Nicolaevich Berezin, a renowned Russian Orientalist. ${ }^{7}$ Willam O. Beeman and Mohammad B. Ghaffari (2010, pp. 74-93) contributed an article to the collection titled "Acting Styles and Actor Training in Ta'ziyeh". The article deals with various topics including but not limited to performance, skill sets, actor education, and the evolution of ta 'ziya acting styles. Yet another article on ta 'ziya is "Identification and Analysis of the Scenic Space in Traditional Iranian Theater" by Mohammad Reza Khaki (2010, pp. 94-109). Iraj Anvar (2010, pp. 110-121) in his article "Peripheral Ta 'ziyeh: The Transformation of Ta 'ziyeh from Muharram Mourning Ritual to Secular and Comic Theater" explains the development of ta'ziyeh and its transformation to a comical form of theater. He relies on several majlis of ta'ziyeh. "A view from the Inside: The Anatomy of the Persian Ta'ziyeh Plays", by Sādiq Humāyūni, translated by Iraj Anvar. The author writes on music and the performance. He explains about the content of the ta'ziya texts. He adds a translation of a segment of ta'ziya Qasem. ${ }^{8}$ In his article "Garden of the Brave in War: Recollections of Iran" Terence O'Donnell writes about his experience when, for the first time, he sees a ta'ziya performance. The he writes his observance (O’Donnell, 2010, pp. 130-148) ${ }^{9}$. "Karbala Drags Kings and Queens", by Negar Mottahedeh is another article of this collection that is published in The Drama Review. ${ }^{10}$ "Compelling Reasons to Sing: The Music of Ta'ziyeh" is another article in this collection on the subject by Stephens Blum. He explains the music of ta'ziya, its meters, melodies and the ta'ziya performers voices. ${ }^{11}$ Hamid Dabashi "Ta'ziyeh as Theater of Protest", published in The Drama Review Journal. "Shiite Narratives of Karbala and Christian Rites of Penance: Michel Foucault and the Culture of the Iranian Revolution, 1978-79" by Janet Afray. She writes on the essays that Michel Foucault was written during the revolution of 1979. During which he was in Iran and recorded his observations. ${ }^{13}$ Molla Cozart Riggio (2010, pp. 237-253) wrote on "Moses and the Wandering Dervish: Ta'ziya in Trinity College", a ta'ziya performed in Trinity College. "Mohammad B. Ghaffari, Ta'ziya Director, an Interview with Peter J. Chelkowski”. 14

\footnotetext{
7 Calmard, Jean and Jacqueline (2010). "Muharram Ceremonies Observed in Tehran by Iliya Nicolaevich Berezin". In Eternal Performance Ta 'ziyeh and Other Shiite Rituals. Edited by P. J. Chelkowski. London, New York, Calcutta: Seagull Books, pp. 53-73.

${ }^{8}$ Humāyūni, S. (2010). "A view from the Inside: The Anatomy of the Persian Ta'ziyeh Plays". In Eternal Performance Ta 'ziyeh and Other Shiite Rituals. Edited by P. J. Chelkowski. London, New York, Calcutta: Seagull Books, pp. 122-129.

9 O'Donnell, T. (2010). "Garden of the Brave in War: Recollections of Iran". In Eternal Performance Ta 'ziyeh and Other Shiite Rituals. Edited by P. J. Chelkowski. London, New York, Calcutta: Seagull Books, pp. 130-148.

${ }^{10}$ Mottahedeh, N. (2010). "Karbala Drags Kings and Queens". In Eternal Performance Ta ziyeh and Other Shiite Rituals. Edited by P. J. Chelkowski. London, New York, Calcutta: Seagull Books, pp. 149-169. For a brief explanation of the article please see p. 21 in the present article.

${ }^{11}$ Blum, S. (2010). "Compelling Reasons to Sing: The Music of Ta'ziyeh". In Eternal Performance Ta ziyeh and Other Shiite Rituals. Edited by P. J. Chelkowski. London, New York, Calcutta: Seagull Books, pp. 170-177.

12 Dabashi, H. (2010). "Ta'ziyeh as Theater of Protest”. In Eternal Performance Ta 'ziyeh and Other Shiite Rituals. Edited by P. J. Chelkowski. London, New York, Calcutta: Seagull Books, pp. 178-191. For a Brief explanation please see p. 21 of this article.

13 Afray, J. (2010). "Shiite Narratives of Karbala and Christian Rites of Penance: Michel Foucault and the Culture of the Iranian Revolution, 1978-79”. In Eternal Performance Ta 'ziyeh and Other Shiite Rituals. Edited by P. J. Chelkowski. London, New York, Calcutta: Seagull Books, pp. 192-236.

${ }^{14}$ Mohammad, B. G. (2010). "Ta'ziya Director, an Interview with Peter J. Chelkowski”. In Eternal Performance Ta'ziyeh and Other Shiite Rituals. Edited by P. J. Chelkowski. London, New York, Calcutta: Seagull Books, pp. 254-271.
} 
"Presenting Ta'ziya at Lincoln Center" by Nigel Redden. ${ }^{15}$ It is worth noting the mentioned articles in the collection are illustrated.

In the same year (2010), Husein Ismā'ili translated and published a collection of ta'ziya texts entitled Tešna dar miqātgah, matn va matnšenāsi-ye ta ziya (Thirsty in the Place of Meeting: Text and Knowing ta'ziya Text). This collection, published in 1928 by the German diplomat Wilhelm Litten, is the first ta'ziya collection to be published in Persian in the nineteenth century, according to Ismā'ili. The book contains 15 gatherings or majles of ta'ziya and begins with mourning for the sacrifice of Ismael (ta'ziya qurbāni kardan-e Ismā‘il) and ends with mourning for Amir Teymūr (ta'ziya Amir Teymūr). At the beginning of each majles, Ismā'ili has added an introduction (darāmad) that consists of an explanation about the gathering afterwards. Under the heading of the origin of majles (khāstgāh-e majles), he notes the Shiite sources from which the main theme of the majles is derived; then, in the copies of majles (nuskhahāy-e majles), Husein Ismā'ili refers to the collections in which the majles is mentioned. This work contains manuscripts of several majles-e ta'ziyas. ${ }^{16}$

In 2011, William O. Beeman published an invaluable book entitled Iranian Performance Tradition. He explains Iranian behavior and norms in order to offer a deeper understanding of Iranian culture to the reader. In the fifth chapter of his book, Beeman sketches a historical development of ta'ziya in Iran. He examines the development or decline of ta 'ziya in different historical periods. He observes theatre, both comedy and tragedy, and holds that they have their roots in Iranian tradition. Beeman illustrates the connection between performance activity and daily life in Iran. In other words, ceremonies that reflect lives and the ideals of the Iranian community are illustrated. In the sixth chapter of his book, Beeman writes about the symbolic conventions of ta'ziya performance. The author looks through the ta'ziya performance from a social point of view and that how the audience connects himself/herself to the whole performance and the event. Actors styles and the way that they are trained, how they receive their non-official education, developing their reciting skills, and their body skills that are derived from traditional zūrkhāna ('house of strength'). The book contains photos from ta'ziya performance scene. The book covers a wide range of subjects about Iranian life, behaviors, folk culture, religious rituals, rūhowzi comedy, media and the Revolution (1979). ${ }^{17}$ Rezā Kūchekzāda (1389) published a collection of šabih-nāma. This collection is the list of the šabih-nāmas written in Qājār period. The author has collected a large number of the šabih-nāma manuscripts mentioning several characteristics of each of them such as the names of the characters, the form of the manuscripts, the objects, the date of compilation and verses that each manuscript begins and ends with. Photos of manuscripts illustrate the book.

Another valuable work published in 2011 is Shi'i Islam in Iranian Cinema: Religion and Spirituality in Film by Nacim Pak-Shiraz. In the fifth chapter of her book Cinema as Reservoir for Cultural Memory, after explaining the historical background of ta'ziya performance, players and limitations for playing their roles, tots and tropes she moves further to explain how ta'ziya is used in Iranian films. She follows the traces of ta'ziya in

\footnotetext{
15 Redden, N. (2010). "Presenting Ta'ziya at Lincoln Center". In Eternal Performance Ta 'ziyeh and Other Shiite Rituals. Edited by P. J. Chelkowski. London, New York, Calcutta: Seagull Books, pp. 272-277. The rest of the articles in the mentioned collection of articles Eternal Performance Ta ziyeh and Other Shiite Rituals are contributed to the ta'ziya ritual in Parma, Iraq, Lebanon, Pakistan and Caribbean.

${ }^{16}$ Tešna dar miqātgah, matn va matnšenāsi-ye ta 'ziya, (majmu'‘ leiten). tashih va tahlil az Husein Ismā'ili. Tehran: Našr-e mo'in, 1389.

17 Beeman, W. O. (2011). Iranian Performance Tradition, Costa Mesa: Mazda Publications, pp. 117-130/147-169. rūhowzi or "over the pool" "is typically performed on a board placed over the pool commonly found in the yard of a Persian home. Rūhowzi usually involves several players engaging in comic dance, music dance, and song. See Daniel, E. L. \& Mahdi, A. A. 2006. Culture and Customs of Iran, Westport: Greenwood Press, p. 93.
} 
the films made by the Iranian film-makers Bahrām Beyzāi and 'Abbās Kiārustami. Nacim Pak-Shiraz explains how Bahrām Beyzāi used ta'ziya ritual in his film titled The Day of Incident (Ruz-e Vāqe'a) written in 1984 while making a reference to the film episodes she explains the foreground of ta'ziya and particularly the day of 'Āšūrā. Another film made by Bahrām Beyzāi is The Travelers (musāferān) where he uses ta'ziya elements such as "lack of suspense, veiled moments of death, and ..." as Pak-Shiraz says. Afterwards, she examines 'Abbās Kiārustami's installment Negāhi be ta'ziya (A Glance to Ta'ziya) staged in 2005 at London Victoria and Albert Museum. She offers a general overview of the installment. The book is illustrated with several images (Pak-Shiraz, 2011, pp. 123-163).

\section{European Travel Accounts on Ta'ziya}

Citing another, yet older, source of literature on passion plays, ta'ziya processions are vividly portrayed in European travel accounts written during the sixteenth and seventeenth centuries. They provide valuable descriptions of the objects used in ta'ziya performance, in addition to the scenes and players. A detailed description of the events at Karbala is preserved in the works of the European traveller Pietro Della Valle. Significantly, he documents the 1618 Muharram ceremonies in Isfahan. Cornelis de Bruyn, a Dutchman, describes a ta'ziya scene in his work Travels into Muscovy and Part of the East-Indies. Likewise, William Franklin, in his Observations Made on a Tour from Bengal to Persia, reports on a ta'ziya procession, consequently revealing the rapid development of ta'ziya in the second half of the seventeenth century (Ter Haar, 1993, pp. 163-5). Morier's travel account titled Second Journey through Persia, Armenia, and Asia Minor between the Years 1810-1816, written in 1818, observes a form of ta'ziya performed before the king and his courtiers. The author illustrates how the objects used in the performance symbolically represented Husein's death at Karbalā. Morier (1818, pp. 176-184) also divulges in detail various other aspects of the performance, even decorating his work with several illustrations.

James Bassett is another traveller-observer of Muharram ta'ziyas. In his 1887 work Persia the Land of the Imams: A Narration of Travel and Residence 1871-1885, he explains the theatrical features of these ceremonies and the ostensibly pathetic stories that are read during the performance. According to Bassett, on the tenth day of the Muharram, members of the procession donned white clothing resembling shrouds, while walking with bare heads and feet. Later, they wounded their heads with sharp blades. ${ }^{18}$

There is yet another vivid portrayal of ta'ziya performance in A Narrative Journey into Persia and Residence at Tehran by J. M. Tancoigne. He not only describes the procession of mourners, but also illustrates how the events of Karbalā and Husein's martyrdom are expressed in the nineteenth century (Momen, 1985, pp. 241-2).

Passion play processions and various forms of flagellation are also explained in travel accounts by Europeans. From a European perspective, these acts are important because they indicate that the mourning procession has theatrical features. Jean Chardin offers a vivid description of sina-zani (beating one's chest) that he witnessed in $1667 .{ }^{19}$ The ta'ziya procession is also described by Pierre Ponafiedine in his travel account entitled Life in the Moslem East (1910). He describes the procession of the mourners. For instance, they not

\footnotetext{
${ }^{18}$ Bassett, J. (1887). Persia the Land of the Imams: A Narration of Travel and Residence 1871-1885. London: Black \& Son, p. 306.

19 See Ter Haar, J. G. J. (1993). "Ta'ziye: Ritual Theater from Shiite Iran”. In Theatre Intercontinental: Forms, Functions, Correspondences. Edited by C. C. Barfoot \& C. Bordewijk, Amsterdam: Rodopi. p. 163.
} 
only inflicted wounds on their bodies, but also hung padlocks, daggers and horseshoes on their backs, arms and breasts. The mourners wounded their foreheads and shaved their heads, motivated by the belief that they would receive a reward. The author further mentions that throughout the first ten days of the month of Muharram, both non-Qur'ānic and Qur'ānic stories were used to show the sufferings of Imam Husein and his family (Ponafidine, 1911, pp. 341-47).

The Shia World (1910) by Muhammad Huseyn Khān Esfahāni provides a short but vivid description of a ta'ziya procession in the city of Yazd. In this travel account, Esfahāni illustrates how the procession was characterized by several theatrical features symbolically depicting the events of Karbalā. Like Morier, he uses an illustration, though, in this case, to visually demonstrate what the procession leaders looked like (Esfahāni, 1910, pp. 191-201).

\section{Translations in European Languages}

Moreover, several translations of passion play performance also exist. Thirty seven majles of ta 'ziya have been translated into English by Lewis Pelly. It was during his journey to India and Iran when Pelly became intrigued by the ta'ziya performance. He dedicated two volumes of his 1879 work The Miracle Play: Hasan and Husain to this invaluable task. The first volume starts with the ta "ziya of "Joseph and his Brethern" and then proceeds to sketch the events leading up to "the death of "Ali Akbar", who was Husein's son. The second volume begins with the death of Qāsim, the Bridegroom, and culminates in the scene of the Resurrection. Also of note, Pelly (1879) writes a short introduction at the beginning of each majles.

Edward Brown, in his invaluable A History of Persian Literature in Modern Times (1924), offers an English translation of ta'ziya martyrdom of Muslim ibn 'Aqil (ta'ziya šahādat-e Muslim ibn 'Aqil) (Brown, 1924, pp. 190-193). Two ta'ziya majles have been translated into French by Louis Massignon and Parviz Mamnoun: Le Majlis de Mansur-e Hallaj, de Shams-e Tabrezi et du Molld de Roum, in Revue des Etudes Islamiques (1955), and Par Ta'ziya: Schi'itisch-Persisches Passionsspiel (Vienna, 1967), respectively.

Two majleses of ta'ziyas have been translated into French by Louis Massignon and Parviz Mamnoun: Le Majlis de Mansur-e Hallaj, de Shams-e Tabrezi et du Molld de Roum, in Revue des Etudes Islamiques (1955), and Ta'ziya: Schi'itisch-Persisches Passionsspiel (Vienna, 1967), respectively. Seyed Abbas Banisadr's book La Tầziye ou Le Drame Persan (1994) contains comparative Persian French translation of two ta 'ziyas; ta'ziya Tamerlane and ta'ziya les Exactions du Regisseur. In the introduction of his book, Banisadr (1994) offers some information about the development of ta'ziya, its language style and the religious and political aspects of ta'ziya.

In 2013, Mahnia Nematollahi Mahani, in her scholarly work, The Holy Drama: Persian Passion Play in Modern Iran, translated one majles of ta'ziya titled majles-e ta'ziya-ye Šām (ta'ziya of the Damescuse Bāzār (Majles-e ta'ziya bāzār-e Šām). The text is in both Persian and English languages (Nematollahi Mahani, 2013, pp. 112-201).

\section{References}

'Anāsuri, J. (1372a). Bahr-e tavil khāni: šiva'i az petwāzh gūi va manzūma khāni-ye namāyeši dar qalamrow-e šabih khāni 'durdānahā-ye sukhan bar sulk-e mahan (Reciting Long-meter: A method of Petwāzh and reciting performance narrative in the realm of šabih-khāni, Eloquent Pearls on the String of Grief). In J. 'Anāsuri (Ed.), Šabih-khāni, ganjina-ye namāyešhā-ye 'à'ini, mazhabi (Reciting Alike, Treasury of Religious Performances). Tehran: Rāmin Printing Office.

'Anāsuri, J. (1372b). Ta‘ziya va marāsem-e 'azādāri dar Pākestān (Ta'ziya and Mourning Rituals in Pakistan). In J. 'Anāsuri (Ed.), 
Šabih-khāni, ganjina-ye namāyešhā-ye 'ā'ini, mazhabi (Reciting Alike, Treasury of Religious Performances). Tehran: Rāmin Printing Office.

Aghaie, K. S. (2004). Martyrs of Karbala: Shi 'i Symbols and Rituals in Modern Iran. Seattle: The University of Washington Press. Aghaie, K. S. (2005). The gender dynamics of Moharram symbols and rituals in the latter years of Qajar rule. In K. S. Aghaie (Ed.), The Women of Karbalā: Ritual Performance and Symbolic Discourses in Modern Shi 'i Islam. Austin: The University of Texas Press.

Ahmadi, H. (1372). Ta'ziya va marāsem-e 'azādāri dar afḡānestān (Ta'ziya and Mourning Rituals in Afghanistan). In J. 'Anāsuri (Ed.), Šabih-khāni, ganjina-ye namāyešhā-ye 'ā'ini, mazhabi (Reciting Alike, Treasury of Religious Performances). Tehran: Rāmin Printing Office.

Amini, J. (1372). Pišina va tārikhča-ye ta'ziya dar Irān (Background and the short history of Ta'ziya in Iran). In J. 'Anāsuri (Ed.),

Šabih-khāni, ganjina-ye namāyešhā-ye 'à'ini, mazhabi (Reciting Alike, Treasury of Religious Performances). Tehran: Rāmin Printing Office.

And, M. (1372). Ta'ziya: trazhedi dar Islam (Ta'ziya: Drama in Islam). In J. 'Anāsuri (Ed.), Šabih-khāni, ganjina-ye namāyešhā-ye 'à'ini, mazhabi (Reciting Alike, Treasury of Religious Performances). Tehran: Rāmin Printing Office.

Ansary Petty, R. (2005). The Ta'ziyeh of the Martyrdom of Hussein. The Drama Review Journal, 49(4), T118.

Ayoub, M. (1978). Redemptive suffering in Islām: A study of the devotional aspects of 'Āshūrā in Twelver Shi'ism. The Hague: Mouton Publishers.

Āzhand, Y. (1385). Namāyeš dar dowra-ye Safavi (The Play in Safavid Period). Tehran: Farhangestān-e HunarPublisher.

Banisadr, S. A. (1994). La Tầziye ou Le Drame Persan (Ta'ziya or Persian Drama). Vancouver: A.J. Print.

Bassett, J. (1887). Persia the Land of the Imams: A Narration of Travel and Residence 1871-1885. London: Black \& Son.

Beeman, W. O., \& Ghaffari, M. B. (2005). Acting Styles and Actor Training in Ta'ziyeh. The Drama Review, 49(4), 48-60.

Behnūdi, M. (1372). Asnād-e vizha-ye šabih-khāni dar Tekiyya Dowlat (Valuable Documents on šabih-khāni in Tekiyya Dowlat).

In J. 'Anāsuri (Ed.), Šabih-khāni, ganjina-ye namāyešhā-ye 'à'ini, mazhabi (Reciting Alike, Treasury of religious performances). Tehran: Rāmin Printing Office.

Brown, E. G. (1924). A history of Persian literature in modern times (A.D. 1500-1924). Cambridge: The University Press.

Bulūkbāši, A. (1383). Ta 'ziya-khāni: hadith-e qudsi-ye masā'eb dar namayeš-e ā'in̄̄ (Performing Ta'ziya: Holy Tradition of Tragedy in Ritual Play). Tehran: Amir Kabir.

Burney Abbas, S. (2005). Sakineh, The narrator of Karbalā: An ethnographic description of a women's Majles Rituals in Pakistan.

In K. S. Aghaie (Ed.), The Women of Karbalā: Ritual Performance and Symbolic Discourses in Modern Shi 'i Islam. Austin: The University of Texas Press.

Chelkowski, P, J. (1984). Islam in modern drama and Theater. In Die Welt des Islams (New Series, Bd., 23/24).

Chelkowski, P. J. (1372). Ta'ziya dar miyān-e musalmānān-e ši'a (Ta'ziya among the Shiite Muslims). In J. 'Anāsuri (Ed.), Šabih-khāni, ganjina-ye namāyešhā-ye 'à'ini, mazhabi (Reciting Alike, Treasury of religious performances). Tehran: Rāmin Printing Office.

Chelkowski, P. J. (1971). Dramatic and literary aspects of Ta'zieh-khāni Iranian passion play. In A. Paolucci \& J. Haidari (Eds.), Review of National Literature (vol. II).

Chelkowski, P. J. (1984). Islam in modern drama and theater. In Die Welt des Islams (New Series, Bd. 23/24).

Chelkowski, P. J. (1985). Shia Muslim Performance. In The Drama Review Journal (vol. 29).

Chelkowski, P. J. (1986). From Maqātil Literature to Drama. In al-Terāt (vol. XII). London: Routledge \& Kegan Paul plc.

Chelkowski, P. J. (1986). Popular Shī‘̄i Mourning Ritual. In al-Terāt (vol. XII). London: Routledge \& Kegan Paul plc.

Chelkowski, P. J. (2005). From the sun-scorched desert of Iran to the Beaches of Trinidad Ta'zieh's Journey from Asia to the Caribbean. The Drama Review Journal, 49(4), T118.

Chelkowski, P. J. (2005). Iconography of the women of Karbalā: Tiles, murals, stamps, and posters. In K. S. Aghaie (Ed.), The Women of Karbalā. Austin: The University of Texas Press.

Dabashi, H. (2005). Ta'ziyah as Theater of Protest. The Drama Review Journal, 49(4), Special Issue on Ta'ziyeh.

Daniel, E. L., \& Mahdi, A. A. (2006). Culture and Customs of Iran. Westport: Greenwood Press.

Deeb, L. Z. (2005). From Mourning to Activism: Sayyedeh Zaynab, Lebanese Shi 'i Woman, and the Transformation of Ashura. In K. S. Aghaie (Ed.), The Women of Karbalā. Austin: The University of Texas Press.

Du Zhanr, R. H. (1372). "Majles-e šahādat-e 'Ali Akbar (PBUH)” (The Assembly of 'Ali Akbar Martyrdom). In J. 'Anāsuri (Ed.), Šabih-khāni, ganjina-ye namāyešhā-ye 'à'ini, mazhabi (Reciting Alike, Treasury of religious performances). Tehran: Rāmin Printing Office. 
Esfahāni, M. H. K. (1910). The Glory of the Shia World: The Tale of a Pilgrimage. Sykes, London: Macmillan \& Co.

Faique, M. (1999). A complete study of Persian Drama 1906-1995. Delhi: Nice Books.

Fernea, E. W., \& Bezirgan, B. Q. (2005). Women's religious rituals in Iraq. In K. S. Aghaie (Ed.), The Women of Karbalā. Austin:

The University of Texas Press.

Fischer, M. M. J. (1980). Iran: From religious dispute to revolution. Cambridge: Harvard University Press.

Flaskerud, I. (2005). Oh, My Heart is Sad, It is Moharram, the Month of Zaynab: The Role of Aesthetics and Women's Mourning in Ceremonies in Shiraz. In K. S. Aghaie (Ed.), The Women of Karbalā. Austin: The University of Texas Press.

Floor, W. (2005). The History of Theater in Iran. Washington D.C.: Mag Publishers.

Ghadially, R. (2005). Gender and Moharram Rituals in an Isma‘ili Sect of South Asian Muslims. In K. S. Aghaie (Ed.), The Women of Karbalā. Austin: The University of Texas Press.

Hegland, M. (1983). Two Images of Husein: Accommodation and revolution in an Iranian village. In N. R. Keddie (Ed.), Religion and Politics in Iran: Shi ism from Quietism to Revolution. New Heaven \& London: Yale University Press.

Hegland, M. E. (2005). Women of Karbalā Moving to America: Shi'i Rituals in Iran, Pakistan, and California. In K. S. Aghaie (Ed.), The Women of Karbalā. Austin: The University of Texas Press.

Heyder, S. A. (2005). Sayyedeh Zaynab: The Conqueror of Damascus and beyond. In K. S. Aghaie (Ed.), The Women of Karbalā: Ritual Performance and Symbolic Discourses in Modern Shi 'i Islam. Austin: The University of Texas Press.

Humāyūni, S. (1354). Ta 'ziya va ta 'ziya-khāni (Ta'ziya and Reciting Ta'ziya). Tehran: bist-o panjom-e šahrivar Printing house.

Humāyūni, S. (1377). Shiraz khāstgāh-e ta 'ziya (Shiraz: The Original Home of Ta'ziya). Shiraz: Fars-šenāsi Institution Press.

Humāyūni, S. (2005). A view from the inside, the Anatomy of the Persian Ta'ziyeh Plays. The Drama Review, 49(4), T118.

Kāšāni, S. M. (1350/1971). Ta ziya Hurr, muqābela, muqaddama va šarh-e ejrā Parviz Sayyād (Ta'ziya Hurr, corrections, introduction and explanation of the performance by Parviz Sayyād). Foundation for Arts Festival.

Khušnevisān, B. (1372). Naq̌̌se lebās dar ta'ziya (The Role of Dress in Ta'ziya). In J. 'Anāsuri (Ed.), Šabih-khāni, ganjina-ye namāyešhā-ye 'ā'ini, mazhabi (Reciting Alike, Treasury of Religious Performances). Tehran: Rāmin Printing Office.

Korom, F. J. (2003). Hosay Trinidad: Muharram Performances in an Indo-Caribbean Diaspora. Philadelphia: University of Pennsylvania Press.

Kūchekzāda, R. (1389). Fehrest-e tusifi-ye šabih-nāmahā-ye dowra-ye Qājār (šabih-nāmahā-ye ganjina-ye khatti-ye ketābkhāna-ye majles-e šurā-ye estāmi) (A Descriptive List of šabih-nāmas Written during Qājār Period (šabih-nāmas in the Treasury of Manuscripts in the Library of Islamic Council of Parliament)). Tehran: Ketābkhāna, mūza va markaz-e asnād-e majles-e šurā-ye eslāmi.

Malekpour, J. (1363). Adabiyyāt-e namāyeši dar Iran (The Performance Literature in Iran). Tehran: Tūs.

Malekpour, J. (1366). Seyr-e tahavol-e mazāmin dar shabih khāni (ta‘ziya) (The Evolution of Motifs in šabih-khāni (ta‘ziya)). Tehran: Publication of Extracurricular Office of Cultural Central Bureau of jihad-e dānešgāhi.

Malekpour, J. (2004). The Islamic Drama. London \& Portland: Frank Cass Publishers.

Momen, M. (1985). An Introduction to Shi 'i Islam, the History of Doctrines of Twelver Shi ism. Oxford: George Ronald.

Morier, J. (1818). Second Journey through Persia, Armenia, and Asia Minor between the Years 1810-1816. London: Longman \& et al.

Mostowfi, A. (1997). The Administrative and Social History of the Qajar Period [The Story of My Life] (Vol. 1). From Agha Muhammad khān to Nāser al-Din Shāh (1794-1896). Translated by Nayer Mostofi Glenn. Costa Mesa: Mazda Publishers.

Mottahedeh, N. (2005a). Karbala Drag Kings and Queens. The Drama Review, 49(4), (T118).

Mottahedeh, N. (2005b). Ta'ziyeh: A Twist of History in Everyday Life. In K. S. Aghaie (Ed.), The Women of Karbalā: Ritual Performance and Symbolic Discourses in Modern Shi ' $i$ Islam. Austin: The University of Texas Press.

Muhammadzāda-Seddiq, H. (1372). Hadiqat al-Su'adā' (The Garden of the Fortunate People). In J. 'Anāsuri (Ed.), Šabih-khāni, ganjina-ye namāyešhā-ye 'ā'ini, mazhabi (Reciting Alike, Treasury of Religious Performances). Tehran: Rāmin Printing Office.

Mukhtābād, M. (1372). Jāygāh-e zibā-šenākhti-ye tatbiqi: ta'ziya dar te'ātr-e mu'āser-e jahān (The position of comparative aesthetics: Ta'ziya in the world's modern art). In J. 'Anāsuri (Ed.), Šabih-khāni, ganjina-ye namāyešhāa-ye 'ā'ini, mazhabi (Reciting Alike, Treasury of Religious Performances). Tehran: Rāmin Printing Office.

Naficy, H. (1981). Cinema as a Political Instrument. In Modern Iran: The Dialectics of Continuity and Change. Albany: State University of New York Press.

Nasri-Ašrafi, J. (1383). Namāyeš va musiqi dar Iran (vol. 3). Tehran: Entešārāt-e Nārvan.

Nematollahi Mahani, M. A. (2013). The Holy Drama: Persian Passion Play in Modern Iran. Leiden: Leiden University Press. 
Pak-Shiraz, N. (2011). Iranian Cinema: Religion and Spirituality in Film. London, New York: I.B. Tauris.

Pelly, L. (1879). The Miracle Play: Hasan and Husain. London: WM. H. Allen and Co.

Pinault, D. (1992). The Shiites: Ritual and popular piety in a Muslim community. London: I.B. Tauris \& Co Ltd Publishers.

Pinault, D. (1998). Zaynab bint 'Ali and the Place of the Women of the Households of the First Imāms in Shiite Devotional Literature. In G. R. G. Hambly (Ed.), Women in the Medieval Islamic World Power, Patronage and Piety. New York: St. Martin's Press.

Ponafidine, P. (1911). Life in the Moslem East. London: Hodder and Stoughton.

Rahim-'Ali, E. (1372). Manša'e ta'ziya (The Origin of ta'ziya). In J. 'Anāsuri (Ed.), Šabih-khāni, ganjina-ye namāyešhā-ye 'ā'ini, mazhabi (Reciting Alike, Treasury of Religious Performances). Tehran: Rāmin Printing Office.

Riggio, M. C. (1994). Ta'ziyeh in Exile: Transformations in a Persian Tradition. In C. Davidson \& J. H. Stroup (Eds.), Early and Traditional Drama: Africa, Asia and the New World. Kalamazoo: Medieval Institute Publications Western Michigan University.

Šāh-'Alizādegān, B. (1386). Emkānāt-e fanni dar te’ātr-e Irān: sahna, nūr, sedā, dekur, lebās va āksesovar (Technical Possibilities in Iran's Theater: Stage, Light, Sound, Decoration, Clothing and Accessvar). Tehran: Theater House of Iran.

Shirazi, F. (2005). The Daughters of Karbalā: Images of Women in Popular Shi'i Culture in Iran. In K. S. Aghaie (Ed.), The Women of Karbalā. Austin: The University of Texas Press.

Taqiyān, L. (1374). Dar bāra-ye ta 'ziya va te'ātr dar Iran (About Ta'ziya and Theater in Iran). Tehran: Markaz Press.

Ter Haar, J. G. J. (1993). Ta'ziye: Ritual Theater from Shiite Iran. In C. C. Barfoot \& C. Bordewijk (Eds.), Theatre Intercontinental: Forms, Functions, Correspondences. Amsterdam: Rodopi.

The Shi 'ites: A Short History. 2005. Translated by A. Brown, Princeton: Markus Wiener Publishers.

Vuthūqi Rahbari, A. A. (1386). Ta 'ziya khāni dar šahrestān-e Sirjān (Ta'ziya Performance in the City of Sirjān). Kerman: Center for Studies on Kerman Press. 